
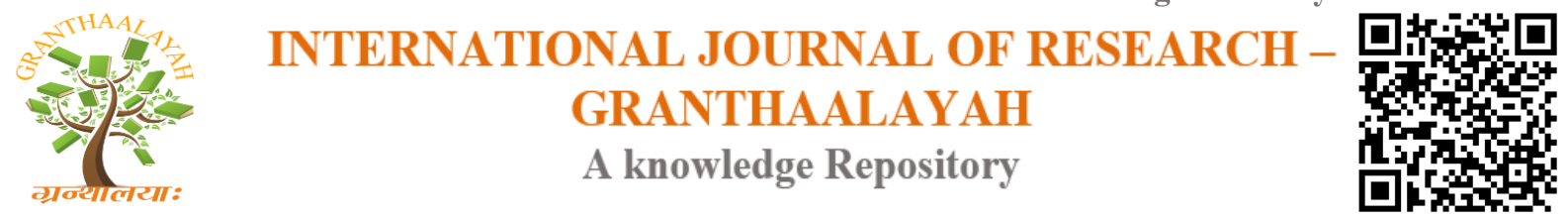

Management

\title{
DEGRADATION OF HUMAN VALUES IN HIGHER EDUCATION: AN ANALYSIS
}

\author{
Pallavi Gupta *1 \\ ${ }^{* 1}$ Assistant Professor, Department of Business Administration, Bhabha Institute of Technology \\ Kanpur, U.P, INDIA
}

\begin{abstract}
Values are defined most oftenly as standards for determining levels of goodness or desirability. Values are generally loaded with affective thoughts about ideas, objects, behavior etc. India's higher education system is one of the oldest systems of the world. In spite of this there is no uniform expansion \& development in this field. Our primordial embodiments i.e. Dharma, Artha, Kama, Moksha, on which education was based, are not even completely realized by scholars today. This is the main reason for degrading the level of human values in higher education in India. On one hand, people are getting rich by the degrees full of knowledge about various fields, simultaneously, loosing values and ethics etc. We ourselves are to be blamed for this. Our existing environment including family system, education system and media including newspapers, T.V. etc is responsible for such poor conditions.

This research paper aims at explaining the factors how \& why human values are consistently degrading in India, as the time passes, although we are rich in culture \& traditions, still our higher education is unable to cherish or enhance it.
\end{abstract}

Keywords:

Values, Primordial embodiments: Dharma, Artha, Kama, Moksha.

Cite This Article: Pallavi Gupta, "DEGRADATION OF HUMAN VALUES IN HIGHER EDUCATION: AN ANALYSIS" International Journal of Research - Granthaalayah, Vol. 4, No. 1 (2016): 165-170.

\section{INTRODUCTION}

In ancient times, India had the Gurukula system of education in which anyone who wished to study went to a teacher's (Guru) house and requested to be taught. If accepted as a student by the guru, he would then stay at the guru's place and help in all activities at home. This not only created a strong tie between the teacher and the student, but also taught the student everything about running a house. The guru taught everything the child wanted to learn, from Sanskrit to the holy Scriptures and from Mathematics to Metaphysics. The student stayed as long as she wished or until the guru felt that he had taught everything he could teach. All learning was closely linked to nature and to life, and not confined to memorizing some information. 
Indian Education system during vedic period had given due importance to the teaching of 'values' to the children. Untiring efforts by some Indian sages and Seers of that time had developed priceless heritage of Indian culture that continued till the end of about 16th Century. After arrival of British Raj, the aim of education underwent a complete change. The British rulers needed cheap clerks to run this country. So they developed a system of education which could produce people to do clerical jobs for them and nothing more. British rulers were also responsible for demolishing Indian Centers of value education like Nalanda University etc.

Education has been a problem in our country and lack of it has been blamed for all sorts of evil for hundreds of years. Even Rabindranath Tagore wrote lengthy articles about how Indian education system needs to change. We have established IITs, IIMs, law schools and other institutions of excellence still question of degrading human values is in higher education is the most burning problem of the country.

India is considered the country of religions, traditions \& recognized worldwide for its culture \& values. But as the standard of values of human is getting down. It is raising a big question mark on our education system.

From administration point of view, there are basically following types of universities in India: Central Universities (46)

State Universities (339)

Deemed Universities (126)

Private Universities (225)

In India approximate 736 universities are operated which are accountable for providing Higher Education in the field of Engineering, Management, Medical, Humanities, Sports \& other Sciences. These degrees are making youth knowledgeable simultaneously preparing them for suitable profession selected by them. Even then it is quite shocking that no Indian university ranked within 100 in the ranking of best universities operated worldwide, while in ancient times we were blessed with one of the oldest universities in world like Takshshila.

Our today's education is proved failure in nurturing our ancient culture \& values. Those practical embodiments which are given importance in human species and through which human behavior is directed \& controlled are known as human values. In each religion there are some moral rules $\&$ the followers of the same ought to follow those rules \& responsibilities throughout their lives. In Philosophy "People's Perception towards life is considered as human values."

Some other people accept that values are deeply rooted in our heritage \& Culture. Any culture is identified by its values only. Our Indian culture is recognized worldwide unique because it is blossomed values. For example in Hindu's perception there are four primordial embodimentsDharma, Artha, Kam \& Moksha and Five practices- Satya, Ahinsha, Astaya, Aparigrah, \& Brahmacharya.

In nutshell, it can be said that human values, Morality \& Character all these are interrelated with human behavior and behavior adopted by human beings who are advantageous for everyone in 
society is known as human values. Recent crisis in 'values' in our youth has revived concern for value education in India.

\section{OBJECTIVES}

1) To understand the meaning of human values, its need \& importance.

2) To point out the factors responsible for degradation of human values in higher education in India.

3) To study the impact or challenges to society and nation at large due to degradation of human values.

4) To give suggestions to improve the condition of higher education in India.

\section{REASONS FOR DEGRADATION OF HUMAN VALUES IN HIGHER EDUCATION}

There are several factors with the modern higher education which are making people literate or educated undoubtedly but on the other hand responsible for forgetting the basics or values of a good human being or a responsible citizen of the society.

\section{LACK OF LEARNING POSITIVE ATMOSPHERE}

Before entering into higher education children live with their families \& pass a large time of their life with the society. Generally their understanding about right \& wrong \& basic values are developed up to intermediate. They learn various ideals, basic principles, determinants \& parameters of behavior from family \& society.

The main responsibility of these higher educational institutions is to modify, enhance \& Strengthen the learnt believes, ideals \& behaviors of the students in right direction.

But at present, higher education institutions are unable to provide such positive atmosphere because the administrations of such institutions are not properly directed. They have forgotten their moral responsibility of providing education service as base of student's bright future by enhancing their own values, they are just working for their monetary welfare. Consequently Universities are unable to execute the system appropriately.

Modern universities have just become source of earning instead of center of education. In such an atmosphere, maintaining human values in itself a great challenge. What to talk about modification \& development of values??

\section{LACK OF ACADEMIC SYLLABUS RELATED TO HUMAN VALUES}

Student's focus have been changed from enhancing hidden talents or values to just make them eligible to earn well or professionally equipped. Now a day, children are educated but they are not aware of the ways of its practical application. Consequently students are unemployed \& depressed as present education makes them job seeker not job maker. It is no more helpful in their social life as well. 
Present education system is making our students such type that they can easily fulfill their basic needs \& earn money but they don't find any importance of values in their lives. If they get job according to their will they are happy $\&$ in case of failure they feel broken $\&$ remain dissatisfied.

\section{LACK OF EXTRA CURRICULAR ACTIVITIES BASED ON HUMAN VALUES}

There is a great importance curricular \& extra-curricular activity for the student's life. But now the scope of extra-curricular activities is been limited to only sports, literary competitions, Quizzes, few games, dance or musical events only.

Morning meetings, prayers, literary works, discussions over social problems and other cultural activities have been disappeared.

Today, on the occasion of birth anniversary of any legends of our history or culture there is holiday. Teachers \& Students stay away from discussion of these topics. And if there is open debate on such things so people are more focused toward win not on the real importance of discussion or learning of morals.

In the same manner on the national festive are celebrated just for the sake of formality. Flag hoisting and general activities are performed but nobody talks about national welfare \& development.

\section{CHALLENGES}

The future growth of any country depends on its youth. Unfortunately, youth in India is getting increasingly inclined towards violence, social evils and lack of respect towards elders \& teachers. Deterioration of human values has become a phenomenon in many nations, including India. This trend of decline in human values does not only pose serious threat to the future course of development of the country but even for its survival, respect and authority itself.

Though, change in social/human values in younger generation is inevitable with time but the decline in Indian younger generation is at an alarming rate as compared to any other country all over the world. It devolves on the parents, teachers and society to imbibe the desired human values in the younger generation.

Due to lack of proper value education in colleges, society is facing many problems. Some facts related to this problem are given below:

- Violation of human rights is a regular feature by persons in power or persons.

- Woman and children are abused in every place.

- Moral and ethical values exist in name only. No practices of values are found at any work place. Rules are made to be broken.

- Increased sense of Materialism in students is one of the factors causing psychological problems among them. 


\section{CONCLUSION}

Today we have entered into $21^{\text {st }}$ century and our country is somewhere lost under the influence of western culture. Knowledge without values is not only useless but is dangerous too for the society.

If within the time focus will not be shifted towards degradation of human values in higher education system it can results in to dangerous outcomes. The basic responsibility of our education system is to protect our culture \& values by originating the seeds of culture in student's characters.

Consequently our leaders of glorious history $\&$ their values will be cherished by the students $\&$ they will be able to protect basic values in the present modern world.

To-day students are taught that 'All is well that ends well' As such our youth today care only about the end results and give no importance to means. They are taught that everything is fair in love and war. As a result we find that our youth is not bothering much about laws of society. Today, students acquire some high degrees and become egoistic in the society.

If human values take root in the educational system, the emerging individuals will have the following attributes:

- They will want peace \& justice in a world that acknowledges the rule of law and in which no nation or individual needs to live in fear.

- Freedom and self-reliance to be available to all.

- The dignity \& work of every person to be recognized \& safeguarded.

- All people to be given an opportunity to achieve their best in life.

- They will seek equality before the law and the equality of opportunity for all.

Value education is ingrained in every tradition of Indian culture. Yet it is a matter of great regret that gradually we are lasing our values with the result that we tend to become cornet and hypocrite. This trend must be checked urgently. Perhaps a major responsibility for the corrective action lies on our teachers, education policies and syllabus.

\section{SUGGESTIONS}

Our education system should try to be focused towards its quality up gradation not only in terms of degrees but also in its application \& practices.

Education must teach a person what life is and what its goal is. It must purify the heart and clarify the vision. It must promote virtues to raise the moral, spiritual and social standards of the educated. The problem and failure of managements is all because of prejudices, biases, subjectivity- all this is taken care by being appreciative of the prepositions of spirituality as taught by our great philosophers. There is need to stress on Indian culture and spirituality in our management courses. 
Higher Education in the present era of LPG is stimulated by economic consideration without any reference to age old human values that separate man from animals. Cut throat competition to achieve material success has made man mechanical. Results of such rat race in the field of education and economic life can be seen in terms of insecurity, distrust, lack of fellow feeling, lack of honour for human values etc. leading to discontent and maladjustment in personal and social life and finally leading to drug abuse, maladjustment and even suicide among students.

It is here that the urgent need for value education is felt by one and all currently. Values in higher education make one's own life and the life of his fellow beings lively and meaningful. Is there any meaning of being educated if the educated man is still away from getting a way of life and redeeming from the disastrous and life-killing ideologies?

The purpose of education is self-affirmation and not self-negation. It is the process of removing the self-negating ideologies in order of self-affirmation. Value education alone can provide real meaning and content in life.

The following are some reasons that may be mentioned in this connection:

- It is very essential that moral awareness is promoted to orient the progress in science and technology towards the welfare of mankind.

- Some common values should be re-discovered to unite human beings.

- Role of Teacher should be enhanced same to previously accepted in ancient times.

- It cannot be ignored that the rate of juvenile delinquency is increasing everywhere. It is a definite symptom of a crisis which today's youth undergoes in the process of his personal growth. In such a situation value education assumes a special significance.

- Human beings should not be treated as saleable commodity that can be disposed of when they cannot help the material cause.

\section{REFERENCES}

[1] International Journal of Emerging Research in Management \&Technology ISSN: 22789359 (Volume-2, Issue-9) "Value Based Education -- Need of the Day"

[2] International Journal of English language Literature \& Humanitites ISSN 2321 -7065 (Volume II Issue I, April 2014) "Importance of Human Values in the Society"

[3] Sindhwani, A. \& Kumar, R. / Educationia Confab ISSN: 2320-009X "Values in Higher Education: Need and Importance"

[4] http://education.newkerala.com/india-education/Brief-History-of-Education-inIndia.html

[5] http://www.gnu.org/education/edu-system-india.en.html

[6] http://startup.nujs.edu/blog/indian-education-system-what-needs-to-change/

[7] http://www.ugc.ac.in/oldpdf/alluniversity.pdf

[8] http://www.indigenousherald.com/index.php/education/97-values-education-and-humanrights-challenges-and-suggestions

[9] http://www.ijaiem.org/volume2issue12/IJAIEM-2013-12-06-011.pdf

[10] https://en.wikipedia.org/wiki/History_of_education_in_the_Indian_subcontinent 